\title{
An Oracle of Ashes: The Burial of James Purdy
}

\author{
By Maria Cecilia Holt \\ Independent Scholar
}

\begin{abstract}
James Purdy (b. 1914), an American writer known for his grim humour and embrace of the outlandish and estranged, died in 2009, shortly after uttering his final wish: that after cremation his ashes should be buried near to Dame Edith Sitwell, one of the earliest and staunchest supporters of his works. This essay chronicles the journey of Purdy's ashes from New York, USA, to Northamptonshire, UK, where they were laid to rest ten years after his death, and it explains how the present writer came to know Purdy not only through his novels, plays and poems, but also through working with Purdy's literary executor, John Uecker, who also served as an assistant to Tennessee Williams. Necessarily autobiographical in certain passages, this essay tells of the discovery of grief in the process of planning the burial, of the power that can inhere in the materiality of cremated remains, and of the legal and logistical complexities of plotting interment across international borders.
\end{abstract}

Keywords: James Purdy, funeral, grief, ashes, Dame Edith Sitwell, Tennessee Williams

Dedication: for John Uecker

This essay tells the story of the funeral of James Otis Purdy (b. 1914), the American writer who died in 2009 and whose last wish was that his ashes should be laid to rest near the grave of the English writer Dame Edith Sitwell (1887-1964). The preparation of James Purdy's burial and its realization in a public ceremony at the churchyard of Weedon Lois in 
Northamptonshire, has been a discursive undertaking: words of planning and proposing, words in applications, the wording of faculties, words incised on stone, words that record, words that memory keeps.

James Purdy was a prolific novelist, playwright and poet, celebrated for works, such as 63: Dream Palace (1956), Color of Darkness (1957), Cabot Wright Begins (1964) and Eustace Chisholm and the Works (1967). His short novel Malcom (1959) was adapted for the theatre by Edward Albee in 1966; Purdy's own play, The Paradise Circus, was given its première in London in October 2018. Purdy had belonged to diverse artistic circles in Chicago (around Gertrude Abercrombie) and in New York (around Carl Van Vechten). As a writer and as a person, James Purdy resisted labels and incited controversy. Defending 63: Dream Palace against the charge of homosexuality, John Cowper Powys wrote a letter to The Observer in 1957 and assured himself of a special place in Purdy's affections. ${ }^{1}$ Purdy's other literary champion was Dame Edith Sitwell, and these two British writers had secured for Purdy's work a London publisher. John Cowper Powys died in 1963, Dame Edith Sitwell in 1964. Purdy, who published Cabot Wright Begins in 1964, felt himself 'orphaned' in America as he had, as yet, no public figures among his admirers there, and mixed reviews would haunt Purdy throughout his life; fame would come, but at a cost.

The words 'dark' and 'gothic' may be among the most frequent terms of evaluation in reviews of Purdy's books, and those terms would elicit wildly different verdicts. One critic would dismiss Cabot Wright Begins as 'Sick outpouring of a confused, adolescent and distraught mind', ${ }^{2}$ while Susan Sontag spoke of the same novel's 'powerful vision of a very real America'. Though critical of Purdy's portrayal of women, Sontag was, in 1964, among the first in America to be appreciative:

Anything Purdy writes is a literary event of importance. He is, to my mind, indisputably one of the half dozen or so living American writers worth taking seriously. ${ }^{3}$

Susan Sontag, Gore Vidal, Paul Bowles, Marianne Moore and other admirers, less famous but no less mindful in their reading of his works, are consistent in their praise of Purdy's command of American 'speech'. ${ }^{4}$ The 'jazz' in Purdy's works has been commented upon by a number of critics and adapters of his works, most recently on the occasion of the première of The Paradise Circus in London in 2018. ${ }^{5}$ Along with the jazz set of $1930 \mathrm{~s}$ Chicago, Purdy's other literary heroes included the outlandish, outsiders and outlaws, in Cervantes, in Greek literature and in the Bible; he was devoted to the Authorized Version. Even as he awakened sympathy for outsiders, Purdy had a way of drawing opprobrium upon himself, perhaps by identifying himself with the outcast. ${ }^{6}$ His grimly humorous disposition 
toward the outrageous struck Dame Edith Sitwell on her first reading of Purdy in 1956; no stranger to the outlandish herself, she described him as 'greater than Faulkner'?

Fifty years on, that claim may seem extravagant though, in time, Dame Edith Sitwell may be justified in her estimation. The present writer, devoted to both, found herself unwittingly tasked with making way for a new generation of literary pilgrims to sites of pilgrimage for both Faulkner and Purdy. On the Anderson Memorial Bridge that spans the Charles River between Boston and Cambridge (Massachusetts) there is a plaque commemorating the death of Faulkner's Quentin Compson, who on 2 June 1910 threw himself off a bridge. In writing The Sound and the Fury, published in 1929, Faulkner would have known that Quentin jumped off the Great Bridge, a wooden construction erected in 1662, which was replaced by the Anderson Memorial Bridge in 1915. The plaque commemorating Quentin's death was first installed anonymously in 1965 . It vanished during the renovation of the bridge in 1983 but was soon replaced (without any authorization from the City) by another plaque. By 2014_during restoration of the bridgethat second plaque had disappeared. In 2016, I enquired of the authorities as to its present whereabouts and prompted a search. The second plaque had been found in the undergrowth nearby, inadvertently discarded; or, as I liked to think, hidden on purpose. The authorities then invited me to choose a new location for the siting of a plaque on the Anderson Memorial Bridge. The flatirons that weighted Quentin down have surfaced again, in the form of a new plaque now installed on the brickwork very close to where the previous plaque had been found, in a place not easily spotted by those crossing the bridge, but now known to pilgrims. ${ }^{8}$

Reinstating a plaque was a simple task compared with that of burying ashes. The last wish of James Purdy, not put in writing but voiced to a single witness as he lay dying, was that his ashes should rest near to the grave of Dame Edith Sitwell. She had noted that Purdy's pages were filled with characters as eccentric and as haunted as Faulkner's; other critics have found in Purdy a blend of the picaresque and the prophetic. Haunt becomes taunt when, in various of Purdy's novels, plays and poems, debts are repaid in cinders; fire is deliberately fuelled by paper that holds a poet's work; blood-money is burnt and delivered in a casket after a father's death; cinders burn holes in the minds of 'bridegrooms' sleepwalking, and widowers drift grief-stricken through mundane tasks. In I am Elijah Thrush (1972), there is a promise to keep a letter until a city-presumably New York- 'is ashes'. ${ }^{9}$ Like Faulkner's, many of Purdy's novels feature a historian, a protagonist obsessed with the past, tormented by riddles of forgotten items, lost persons, bodies missed and missing.

In Eustace Chisholm and the Works (1967) we read: 'I am as surprised to get a letter from you as to hear a tombstone speak'. ${ }^{10}$ In letters and 
interviews Purdy seems unafraid of ghosts and admits to digging his own grave, even dwelling in it, with the help of the literary establishment:

When I write a book, my publishers publish it in the dead of night. They go out in this deserted garden and they dig an eighty-foot pit and put it in [...] then they forget all about it. ${ }^{11}$

Would it be superfluous to bury an author who had so often buried himself? When asked for advice and support, the agent handling Purdy's literary estate responded that the burial of one of her authors did not fall within her purview. An American university where Purdy had taught Spanish for many years likewise declined the invitation to be involved; few were willing to claim kinship or association with James Purdy. By 2015, six years after his death, his fame had declined to the point that he was no longer famous, not even infamous. Those Americans who were approached were respectful but distant: most disclaimed even much knowledge of James Purdy. A number of appeals for funding - to study his words as well as to bury his ashes-were turned down. No one seemed keen to venture into Purdy's deserted garden.

A deserted garden may well describe the state of Purdy's literary reputation-whether in New York or elsewhere-but it is also a suitable place for a writer's casket: a graveyard is surely the very type of a deserted garden. This casket would hold the remains of a body that wrote much of burials, as even the titles indicate: In a Shallow Grave, Mourners Below, Narrow Rooms, The House of the Solitary Maggot, Garments the Living Wear.

Only one part of Purdy's correspondence has to date been published: that with the novelist John Cowper Powys (1872-1963). ${ }^{12}$ In their letters to one another they shared their literary enthusiasms and both extolled Dame Edith Sitwell. Purdy celebrated the beauty of Thomas Browne's works, especially Hydriotaphia or Urn Burial (1658) in which we may read:

[...] who knows the fate of his bones, or how often he is to be buried? who hath the Oracle of his ashes, or whither they are to be scattered? The Reliques of many lie like the ruines of Pompeys in all parts of the earth; And when they arrive at your hands, these may seem to have wandered far, who in direct and Meridian Travell, have but few miles of known Earth between your self and the Pole. ${ }^{13}$

From the late 1950s Purdy accumulated a debt of gratitude towards two English writers, Edith Sitwell and John Cowper Powys; throughout his life he maintained a loyalty to the memory of each. In 2009 Dame Edith's name would be among his very last words; this would be a fitting return 
for her public protest against the suppression of the last word of Purdy's first book, half a century earlier. The first edition of 63: Dream Palace was published by Victor Gollancz in London in 1957 and its last sentence reads 'Up we go then, little bugger'. ${ }^{14}$ In one copy of that edition, Purdy restored in his own hand the last word as submitted: motherfucker, adding 'corrected by the author at the behest of Dame Edith Sitwell. ${ }^{15}$ An image of Dame Edith Sitwell occupied the centre of Purdy's mantelpiece, chief among his household deities: her framed photograph is visible in numerous images of Purdy taken at home. Was Dame Edith, in Sir Thomas Browne's phrase, the oracle of Purdy's ashes? In the Foreword to Purdy's Selected Plays (2009) John Uecker wrote:

Several days after I put this down, Purdy succumbed to complications in the hospital. His body was cremated, and his ashes are to be scattered over Dame Edith Sitwell's grave as was his wish. ${ }^{16}$

While Purdy's 'strange and unsettling fiction' was being rediscovered by readers at the suggestion of Jon Michaud in the New Yorker in 2015, I was travelling that summer (on two separate occasions in June and July) between Boston and New York for a series of meetings with John Uecker, Purdy's literary executor. Uecker had taken upon himself the responsibility to fulfil the wish often expressed to him by Purdy in the days leading up to his death. Initially, however, Uecker and I were concerned not with Purdy, but with materials related to Tennessee Williams's play, In Masks Outrageous and Austere, a unique version of which I conveyed from John Uecker to the Houghton Library at Harvard University.

In the company of Charles Lock, joint editor of Purdy's correspondence with Powys in 2013, I had met Uecker at the American Literature Association (ALA) conference in Washington DC in 2014; the following year, at the ALA conference in Boston, Uecker invited me to visit New York to help him discharge his duties as Purdy's literary executor. Although Purdy's final wishes concerning burial had been discussed by Lock and Uecker early on, Uecker still had matters to settle in Tennessee Williams's estate.

Uecker had been Williams's secretary; he also served as his literary assistant and had edited a number of the late plays including The Traveling Companion. Concerning In Masks Outrageous and Austere, 'Tennessee knew he had a play, but he couldn't find it', Uecker told me. Although he is one of a group of writers credited with having worked on In Masks Outrageous and Austere, ${ }^{17}$ Uecker's contribution has been overlooked, even obliterated, by the scandal and strife that followed the playwright's death in $1983 .{ }^{18}$ Accounts present a broken man surrounded by wine bottles and prescription drugs, yet among the items to be found in Williams's suite at the Hotel 
Elysée in New York was one of Purdy's short stories: 'Some of these Days'a story of anguished love discovered too late, and of longing encrypted in forgotten names. 'It was with him when he died', Uecker told me, 'His head was on the short story!' How it came to be there was almost as much a mystery to Uecker as had been (see below) the arrival of Purdy's book on Dame Edith's bed at Montegufoni. ${ }^{19}$

In 1980 Williams had dedicated a one-act play, 'The Chalky White Substance', to Purdy. Williams also attended Purdy's workshops as well as productions of his one-act plays, and he admired Purdy for writing 'poignantly on the subject of loneliness in our particular world'. ${ }^{20}$ At one performance, Williams was so overcome that he had to leave at the interval: Williams wrote to Purdy, 'Another time, another place? I hope so'. ${ }^{21}$

Much earlier, in 1957, Purdy had confessed to Powys that he had been too frightened to meet the great writer of The Glass Menagerie (1944) and A Streetcar Named Desire (1947):

Tennessee Williams wrote me a long letter and asked me to meet him in New York, but I was afraid to go to see him and anyhow when he wrote I didn't have the money for such a trip and was hiding in the mountains in Pennsylvania, so I never heard from him again. ${ }^{22}$

In 1979 Uecker had arranged a dinner for Purdy and Williams (with Uecker in attendance). By then an established writer, Purdy showed a less fearful and more flirtatious side as he opened the evening's conversation; 'So...' James said to Tennessee 'You know the Snow Leopard...?'23 Purdy's nickname for Uecker had caught Williams off-guard. Snow Leopard was so apt a description of Uecker's physique and presence as cat-like guardian and enigmatic protector that a good-natured battle ensued for the affections of the person who had brought them together, and who would in due course serve as literary assistant to both of them-and, finally, as the custodian of two legacies.

Thirty-six years later, the young man who had been admired and depended upon by those two distinguished writers would be haunted by their deaths and laden with their papers. After Uecker and I had lunch at City Diner on the Upper West Side on 27 June 2015, we agreed to meet at what he called 'the lock-up' on Eighty-Third and Amsterdam: a storage facility that contained the remains of the James Purdy archive, which was destined for the New York Public Library. Except for six unmarked boxes, one on top of another, which held dated drafts of the 'Uecker version' of In Masks Outrageous and Austere, complete with binders of notes and email print-outs from friends, foes, producers and lawyers.

When I informed Uecker that the Houghton Library at Harvard had agreed to accept the Tennessee Williams materials, leaving his part in 
the play's story for future scholars to estimate, ${ }^{24}$ there seemed in his voice something less than celebration, but a grateful sense of respite from grief-and from the injustice that follows a denial of recognition. In midJuly I returned to New York to help him with the work of organizing the inventory.

On 5 July 2015 Lock made formal enquiries about the possibility of burying Purdy's ashes at St Mary's Church, Weedon Lois-the village in Northamptonshire where Dame Edith had been buried in 1964. 'We need to get this done' was Uecker's simple comment; he registered both relief and disbelief that matters concerning Williams and Purdy were being handled simultaneously, and by two strangers whom he had met only the year before. A second brief message from that day: 'I find it hard to believe my good fortune in you. Thank you so very very much'. ${ }^{25}$

On 11 July, in the midst of our work gathering the Uecker version of In Masks Outrageous and Austere, he presented me with Purdy's typewriter, an Olivetti Lettera 32, as a gift for Charles Lock. The day had been a difficult one, Uecker's mood wavering between discipline and distress. He was often an active participant, letting me know the story behind each piece of paper and why or how the various boxes had been organized. We weeded out duplicates, except for one envelope, 'John's Notes', and a box of copies, retained in case the others were lost or damaged during transit. There had been enough misery and mystery surrounding the play's history for me not to question the plan, and at the mailing centre we soon discovered the shipping number we were given was in error by one digit. (Although the mistake was corrected by someone on duty at Houghton Library, this re-awoke Uecker's fear that recognition would again elude him.) At other times, Uecker was overwhelmed, and there would issue forth a familiar refrain of mourning: 'Oh God! Tennessee...' followed by bouts of grieving silence.

When the boxes were ready, we were told we would only be allowed to use a small public elevator. It was of an antique type with scissor-gates that had to be held open manually. I carried at least half of the boxes into and out of the tiny Otis elevator while Uecker hailed a taxi as he guided and guarded the growing pile at ground level. As I scrambled with boxes into the cab-I hadn't forgotten Purdy's Olivetti Lettera 32-Uecker heaved a magnificent sigh as he looked at my rucksack and said, 'That typewriter's going to kill us...'

It didn't. Now that I had helped in securing one legacy (Uecker's gift to Houghton Library of a significant version of Williams's last play) I would be entrusted by Uecker with orchestrating a more challenging production: Purdy's burial. Although Purdy's remains had been cremated following his death in 2009, by 2015 his ashes had still not been buried. Early 
efforts to do so had been thwarted. Enquiries made soon after Purdy's death led to a conundrum: Uecker and Bill Troop (a friend of Purdy's toward the end of the writer's life) had been told that it would be possible to inter the ashes at Weedon Lois but only in an area designated for other cremated remains. This would be within hailing distance of Dame Edith Sitwell but not immediately adjacent to her grave. On 15 July, Charles Lock received a message from the Reverend Carole Peters-King, Rector of Weedon Lois confirming this rule:

Sadly, the Church of England requires that all ashes are buried in a marked space within the graveyard and our memorial garden for ashes is some way from Dame Edith Sitwell's Grave.

However, we could apply to the church to have a special burial closer to the grave-this would require what we call a Faculty and would cost around $£ 200$. Do let me know if you would like to proceed with either option. ${ }^{26}$

Uecker expressed reluctance at making an application for a Faculty, concerned that it would provide only another occasion for delay and rejection. However, he was encouraged by us not only to apply for a Faculty to bury Purdy near to Dame Edith Sitwell, but also to allow the ashes to be carried to Europe at once. I was headed to Europe in early August of 2015, and Lock would be visiting England later that month when he would find time to make a visit to Weedon Lois. It was surely opportune for me to return to New York in order to retrieve Purdy's ashes and carry them to Denmark; they would then be ready for burial in England at whatever date the Faculty might be granted by the Diocese of Peterborough.

While the application was being prepared, I approached the Transportation Security Administration (TSA) and various consulates to find out what paperwork would be needed in order to take cremated remains as cabin baggage on a transatlantic flight. The requirements included a death certificate, a certificate of cremation, and a letter stating where the ashes were to be interred. I was informed that there would be no problem making a stopover in Frankfurt, so long as I did not leave the airport. The representative at the Consulate General of Denmark in New York was impressed that I would be ferrying the ashes of a great writer to their shores, albeit temporarily. She also wished us well, expressing admiration at our efforts to help fulfil a writer's last wish: 'You are good friends'.

Purdy's remains had been cremated in March 2009 at the Garden State Crematory in North Bergen, New Jersey and from there sent to Wien \& Wien Memorial Chapel in Hackensack, from where Uecker collected the ashes. He kept them in his apartment in New York until 1 August 2015 when he gave them to me: 'Here; you better take him before I change my 
mind'. But he would only let me have Purdy's ashes if I would first take a few of them out. 'What if something happens to you, or the ashes?' 'How are we going to bury James next to Dame Edith?' I was prepared for these questions, and prepared to meet even this request in order to fulfil the greater obligation.

How does one take 'some' ashes out of a sealed container? The task is all the more nerve-racking when they are the ashes of a distinguished American writer. Uecker gave me two tools: a small pair of scissors, and a dull serrated knife-which, he told me, I was to plunge into his heart (Uecker's) once the deed was done. Luckily, I had read online a little on the subject of ashes and their casing. In the sealed cardboard container, approximately $7 \times 7 \times 10$ inches (or $18 \times 18 \times 25 \mathrm{~cm}$ ), there would be another box, a temporary urn made of hard plastic, and within this plastic vessel a translucent bag that held the cremated remains. The problem was to decide at which end of the cardboard carton the top of the plastic urn was likely to be, as I did not want to destroy the original carton.

In this task I was left alone while Uecker kept to a corner and watched a film. I called the Keefe funeral home in Cambridge, Massachusetts.

'Come on over. We'll do this for you.'

'I can't. I'm in New York.... How do I not ruin the box?'

'I would try the left-hand side'

'Is what I'm doing ... normal?'

'Yes. Good Luck.'

Funeral homes must entertain a great number of seemingly outlandish requests from bereaved patrons, and I was spurred on by their efficient grace. I determined that the serrated knife was useless, so I worked with the curved scissors, very slowly cutting and peeling away at the strong adhesive tape on the paper carton. Every once in a while, a voice would be heard in the darkness: 'Are you done? Oh God!'

I took great care snipping at just one side of the carton, praying that I would find the top and not the bottom of the plastic urn; if not, I'd have to start all over at the other end and perhaps Uecker's patience would be exhausted, or grief would overwhelm him, and I would be expelled from the apartment without the ashes. Trying to ignore such fears, I continued to work with as much precision as curved scissors would allow. Finally, I was able to cut through the carton where, to my immense relief, the lid of the plastic urn was revealed.

I called Uecker over to his bed where I had been working. His face went from a scowl to one of deep reverence. When the temporary plastic urn was opened, I cleared away sheets of grey paper that had been used as filler and lifted out the plastic bag that contained sand-like ashes. The bag was fastened with a plastic tie and bore a label identifying the remains as those of James Purdy. I took a photograph. We clipped the 
plastic tie (which we later replaced) and with a wooden spoon that I had brought with me, I scooped 'some' of James Purdy's ashes into a jam-jar for safekeeping. ${ }^{27}$ There was calm; John was gentle. He swept the hair from my face as I decanted a few spoonfuls (two or three?) of Purdy's ashes and placed them into the jar. As I stood for the first time in what seemed hours, I noticed a smattering (or a scattering) of ashes upon the coverlet on the bed, a coverlet patterned with small roses: 'As if a rose should change into a ghost - / A ghost turn to a perfume on the leaves'. ${ }^{28}$

On 1 August 2015 I took James Purdy's ashes from John Uecker's apartment in New York and on 6 August they were transported as cabinbaggage on a Lufthansa flight from Boston to Copenhagen via Frankfurt. Purdy's death certificate and an explanatory letter from Uecker were in a folder along with photos of Dame Edith Sitwell's grave, taken from Wikipedia; the cremation certificate was sealed undisturbed atop the lid of the cardboard carton of the cremation box. Although Uecker and I had done our best to re-seal the side of the carton that had been trimmed with scissors, the tape we used was glossy rather than matte, and there were a few loose threads from the old tape still visible. During its several days in Boston, the carton was tidied up and resealed with paper-adhesive identical to what had been used on its unopened edges. Purdy may not have been traveling first-class, but I was determined that he should take his departure from the United States well-groomed and in good order.

I was also determined not to be harassed by TSA officials at Boston's Logan Airport. Forearmed with paperwork, with approval from Lufthansa and various consulates, I placed on the conveyor belt a black case with a combination lock that held Purdy's cremated remains. I imagined protest, delay, further questions, even blasphemy. Instead these words: 'Ma'am, I am sorry for your loss'. Such kindliness was beyond expectation. I had been prepared for diatribe; instead I was rendered mute in the face of a commonplace utterance. I wanted to say: 'It's not my loss, it's yours'. It was then that I realized, for the first time, that Purdy was leaving the United States for ever. I phoned Uecker from the International terminal. We had had many conversations that summer during which he grieved; he told outrageous stories. This time, however, it was I who wept, and Uecker who consoled me. He told me it was right that Purdy was leaving the United States, to go to the land where he first found appreciative readers, and he pronounced: 'America doesn't deserve James'.

In April 2016, after almost eight months of deliberation, the Faculty was granted and permission given, exceptionally, to bury James 
Purdy's ashes in the main graveyard and immediately adjacent to Dame Edith Sitwell's. The distinguished British letter cutter, Nicholas Sloan, was approached, and many discussions followed about the words that should be incised on the stone, and about the style and form of the lettering. The inscription decided upon by Uecker included a short poem by Purdy (Fig. 6):

we who are under the ground

indians and voyagers and wilderness men

still breathe the bloom of plants in air

and think of the running sun

Though the stone had been much discussed and all but commissioned in 2018, the ashes were still unburied. The remains were ready and willing, but the living seemed reluctant. Plans had come to a halt in the autumn of 2017 when the authorities at Weedon Lois informed us of another stipulation from the Diocese of Peterborough: that Purdy's ashes, though interred among graves, could only be commemorated with a flat memorial tablet, not by an upright stone. Memorial tablets, $18 \times 18$ inches and lying flat on the ground, were the standard for cremated remains. No application for another Faculty could be made and no further exception would be granted.

Given the excitement and progress up to that point-especially with regard to an upright stone worthy of its neighbour ${ }^{29}$ - the disappointment came as a shock. This was followed by a renewed wave of grief for Uecker. Disappointed once more, he turned elusive; maintaining contact with him proved challenging. Once we realized that the design for Purdy's memorial would have to be rethought, from an upright stone to a flat stone little bigger than an envelope, a larger concern haunted us all: would James Purdy ever be laid to rest? In the years since the Faculty had been granted, the ashes had been in Lock's apartment in Copenhagen, resting above a substantial collection of Purdy's works. Meanwhile, there had been much ado among the living. I would frequently write to Uecker; Lock and I would, on separate occasions, visit Bill Troop in London; Lock and I would be in communication with the Reverend Carole Peters-King and later with Wiggie Smith and Frank Hunter (respectively lay-reader and church warden of St Mary's, Weedon Lois) about the 'impending burial'. Lock would discuss with Nick Sloan a number of Uecker's stipulations that required modifications to his proposed design of the memorial tablet, and I would, at different times, write or listen to Uecker. His memories of James Purdy - when extracted from the mire of mournfulness-often acted as a spur, a spark in the gloom of delay and deferral. 
From the dead, however, we had heard no complaint nor murmuring of dissent at what was being arranged. I had often thought about how, throughout the long journey from New York, Purdy's ashes had been 'quiet'. The black case hadn't gone missing; nor had the cremation carton slipped from my hands. When the case passed through security in Frankfurt, I was nervous lest the ashes go through a further inspection and be found offending; after all, Narrow Rooms had been charged with 'pornography' in a German court in 1990. (I held my breath as I offered the paperwork.) But after each page had been read aloud, the judge ruled in favour of Narrow Rooms, having heard no evidence of unacceptable levels of indecency: case (and black case) closed! Purdy was not silenced, in Germany, and his ashes made no protest: they were 'silent' about their burial.

Silent that is, except on one occasion: I had arrived in Copenhagen on 7 August 2015. The following morning, I was awoken by three knocks at my heart. They were strong and clear like pounding on hard earth:

boom boom boom

—resounding like the adze in As I Lay Dying. At the third knock, my eyes opened to the early dawn; I felt a tremendous whoosh as of a great rush of leaves or of noisy feathers, though the windows were closed, and there was no sound of wind outside. When I returned to the States, I told Uecker what had happened, suggesting that the spirit had, at that moment, taken its leave of the material remains. (Might this have been the reverse of the motion by which, as we are yet to see, Purdy had first manifested himself to Dame Edith at Montegufoni?)

'Do we still have to bury him?' The very pronoun betrayed the assumption that 'he' was still in the ashes.

'Yes.'

My 'Yes' from 2015 would alternately inspire and provoke me in the months, then years, that followed. In February 2018, I applied for two research grants for a work on burial and oratory, specifically concerned with the term Kairos, or the opportune time for an action, as a moral category little in evidence in contemporary discourse (whether public or academic). Purdy had studied Greek and acquired a facility in reading Classical Greek literature. His works brim with allusions to Greek myths: given that so many of those myths are concerned with funerals and burials, one finds passages in Purdy's writings that seem to foreshadow the story of his own. The fate of Purdy's ashes over ten years could not but suggest the fate of Polyneices's corpse. ${ }^{30}$

For Purdy, words are not inert; they are always participants in some ritual that a casual reader might not notice. The ritual often involves the 
dead-not because Purdy was especially morbid but because the dead test the limits of ritual, and of words. We address the dead at a funeral, in messages that we leave or send; apart from funerals, in non-ritual spaces of daily life and even on social media, ${ }^{31}$ the living circulate their words for and to the dead; many words, whether carefully chosen or 'unbidden', turn out to be about the absent, and addressed to them.

One of the purposes of funeral rituals and their words is to allay grief. Purdy's The House of the Solitary Maggot (1974) opens with the town magnate's death and burial: 'There was no ceremony'. ${ }^{32}$ This is a constant dilemma in Purdy novels and plays: protagonists struggle to make sense of sudden or early deaths, missing persons, disfigured bodies, spaces transformed by war or 'progress' and their own dislocations. Time is a source of wounding and of consolation as characters sort out the histories of towns as well as the hidden lives of loved ones hitherto known only in death. Such narratives can become clear with the help of unexpected strangers from out of town or from 'beyond'.

In at least two interviews (Interview Magazine in 1972 and Penthouse in 1974), Purdy spoke of grief, of ghosts (that of his dead brother paying Purdy a 'visit'), and of ghostliness (his own): 'No one wants to hear about grief anymore', he said in an interview with Stephen Varble in 1972. The supposed refusal by the literary establishment to acknowledge grief as a theme may have contributed to Purdy's metaphor in accusing the literary world of burying his work, but Purdy himself admits to a deeper sense of displacement. When Varble comments that Purdy seems to have been 'in transit most of his life', Purdy responds:

Yes. I don't have any home [...]. Everyone I grew up with, my family, are all dead. So I feel kind of like a ghost. I'm more interested in the past. And a kind of communing with unseen things which is your art, really. ${ }^{33}$

The dead and ghosts frequent the pages of Purdy's novels and plays, reminding readers of the need for ritual, for mourning and remembrance. After hours of listening to him by phone and in person, I acquired a sense of what lay at the heart of Uecker's grief: an empty stage. It had been years since Uecker had been invited to direct a play; to that frustration was added his inability thus far to carry out Purdy's final wishes. After a hiatus of seven to eight months, my contact with Uecker was resumed. It was in London, while visiting Bill Troop in 2018, that I heard Uecker's voice (by telephone) for the first time since collecting Purdy's ashes. And his refrain was unchanged: we had to 'bury James-next to Dame Edith'.

In The Empty Space, a revolutionary work of 1958 that insists on the link between theatre and ritual-even, implicit in the title, between theatre and burial-Peter Brook writes: 
Instinctively, governments know that the living event could create a dangerous electricity-even if we see this happen all too seldom. But this ancient fear is a recognition of an ancient potential. The theatre is the arena where a living confrontation can take place. ${ }^{34}$

Such a confrontation is staged between Creon and Antigone over the corpse of Polyneices, and between Hamlet and Laertes in the empty space of the still unoccupied grave dug for Ophelia. That Purdy considered himself first and foremost a playwright is not widely known; for Purdy, theatre remained a special place of encounter. Uecker would often say that Purdy 'began as a playwright'. In his childhood, as early as the age of nine, Purdy created a cardboard toy theatre and acted out parts in plays that he had devised. He would go on to write numerous plays, few of which were ever produced. Uecker directed several of them, with Victoria Linchong as producer. The plays produced by this collaboration include, in 1989, Sun of the Sleepless (a double-bill comprised of 'Souvenirs' and 'Heatstroke'), featuring Laurence Fishburne and Sheila Dabney, and in 1992, Til the Eagle Hollers, with Jane Smith. Rivalry of Dolls was the first of two full-length plays undertaken by Uecker and Linchong, after which they formed The Running Sun Theater Company and, in 1997, staged Foment. This was reviewed in the New York Press:

Typical of Purdy, it takes about a second for the air to become thick with foreboding, dread and homoerotic fevers; add the uniquely lyrical yet gutsy poetics Purdy's characters speak-they sound like Elizabethan gangstersand you've got a very strange intense theatrical experience you'll either love or hate. ${ }^{35}$

As in his novels and stories, so in his plays: orphans, misfits, outlaws and carnival inverts-fun-turned-dark. On the back cover of Selected Plays John Waters writes that Purdy's plays 'will break your damaged little heart'. Ric Zank, founder of the Iowa Theatre Lab, collaborated with Purdy in the early 1980s on a production in Baltimore, Maryland, and recalled Purdy's sense of mischief as well as gratitude in a series of thank-you notes sent to the cast. One such note was a 'Valentine', profound in its simplicity: four typed words of greeting as if deliberately staged in otherwise empty space.

There was still the empty space in Weedon Lois: the not-yet-occupied lot next to that of Dame Edith Sitwell. Those caring for Purdy's ashes were troubled by these questions: whether the Faculty was still valid, and the site still available. Happily, the answer was always affirmative, however anxious the interval: the permission, once granted, would not lapse.

There had been rumours in February 2018 that The Paradise Circus, printed in Purdy's Selected Plays, was to receive its première at the 
Playground Theatre, Shepherd's Bush, West London. The Theatre's founder and Artistic Director, Peter Tate, had long admired Purdy as a dramatist and over many years had nursed the ambition of staging one of his plays in London. It seemed a good idea to hold Purdy's funeral around the time that a play of his was being staged, for the very first time, in London. A play and a funeral, and an academic symposium: this would draw attention to Purdy, specifically to his work as a playwright, and invite reflection on the positive welcome extended to Purdy's work in Britain since the late 1950s. Various Purdy titles had been published in London by Victor Gollancz, Secker \& Warburg and Jonathan Cape; from 1985 his work was championed by Peter Owen, who remains the most loyal of all Purdy's publishers, whether in the US or the UK.

Having applied for research funding, I travelled to London in late February to ask Bill Troop for his support, and to find out whether there was any truth in these rumours. Though hospitable and generous, Bill Troop nevertheless questioned the feasibility of both artistic and academic endeavours: better to spare oneself the near-certainty of disappointment. But had not Purdy himself said that he liked stories 'that bristled with impossibilities'?36 Recalling Purdy's 'heart-pounding' in Denmark almost three years before, it seemed the time had come for him to be buried in the place he had chosen, no matter how few of us would participate in the ritual. The funeral had to be deferred, but the London première of The Paradise Circus-with Tim Woodward and Sophie Ward-took place on 13 October 2018. ${ }^{37}$ It was attended by, among others, John Uecker, Pamela Malpas (Purdy's agent), Bill Troop, Richard Canning, Charles Lock and myself. Just prior to the performance the play's director, Anthony Biggs, held a conversation on stage with John Uecker and Charles Lock, in which Purdy's literary and dramatic ambitions were considered, and the admiration of Purdy in Britain over sixty years was celebrated. Thus was initiated a sequence of events that would transform the deserted garden, and leave one empty space filled.

The date 13 March 2019 would mark the tenth anniversary of Purdy's death, and this had been entered into the Benefice diary by the Reverend Carole Peters-King. ${ }^{38}$ However, in all of our communications with her since Lock's first visit to Weedon Lois in August 2015, no date had been agreed upon. The spring of 2019 was suitable for all concerned, including, as the host of an academic symposium, the University of Northampton; the Professor of English there was Richard Canning, serendipitously the leading authority on Purdy in the United Kingdom. It was suitable also for the letter-cutter, whose patience was not yet exhausted, though we had so often had to ask for alterations in the design of the stone.

The very date of Purdy's death, 13 March, was agreeable to the Parish Council of Weedon Lois, and we began an intense final stage of planning: 
working with Nicholas Sloan, the letter-cutter; with Frank Hunter, the church warden at St. Mary's; and with Humphris Funerals at Banbury, who would transfer the ashes into a casket for burial; with Richard Canning who would host the symposium; and with the lay-reader, Wiggie Smith, who was asked to use the 1662 Book of Common Prayer for the funeral service. Not the least delicate and intense task was mine: to ensure that John Uecker would, after all, be present at the funeral of James Purdy.

When Uecker wrote in advance of my first visit to him in New York, in 2015, he had miscalculated the date of my arrival: instead of 27 June, he thought I would be arriving on 17 June. His message stayed in my memory as a significant error, even proleptically an accurate one, that would adjust itself as the days turned into years:

Ah ... ten more days ... dear ... I have to accomplish quite a bit in these days.... I can't wait to see you ... but nothing I can do will make the days disappear into the past. ${ }^{39}$

Ten years of Purdy's unburied state are now in the past. That plot of earth in the English Midlands should put visitors in mind of Purdy's loyalty and devotion to Dame Edith Sitwell, and should declare and affirm a transatlantic literary affiliation that would otherwise be obscured. ${ }^{40}$ For some of us, that 'slope of green access' will also recall the obstacles that had to be overcome: practical, of course, in terms of distance and the administrative discourse of ashes, and ideological, in terms of a New Yorker's attitude to an unknown English village, and of the Church of England's attitude to an unknown American writer-however eminent-of no known denominational adherence, whose final wish was to be buried in the Diocese of Peterborough. As for Dame Edith, she was given to oracular pronouncements, and now finds herself companion, custodian and oracle of Purdy's ashes. Both John Cowper Powys and Edith Sitwell died just as Purdy was achieving critical notice (in 1963 and 1964, respectively); each had treated Purdy's friendship with respect and enchantment in equal measure. Purdy admired them both, and addressed Dame Edith as his 'patron saint'. ${ }^{41}$

Elizabeth Salter, her secretary and the author of a memoir, related that Dame Edith's discovery of Purdy was always remembered as 'something of a mystery that was never solved':

She had gone to sleep at Montegufoni one afternoon with the windows shuttered and the doors closed against draughts and intruders as was her custom, and when she woke up there was a book lying on her bed which had not been there when she had gone to sleep. ${ }^{42}$ 
In 2005, reviewing Purdy's Moe's Villa and Other Stories, Gore Vidal recalled that he had first heard of James Purdy while dining with Dame Edith in London. She had told him: 'I have discovered a true American genius. Unknown in your country, I fear. He is called James Purdy'. ${ }^{3}$

At Weedon Lois the hole was dug, made empty, at the far end of the central alley of the graveyard, whose focus is filled by the imposing stone of Dame Edith's monument. The procession began at the gate by the road, headed by the lay-reader, followed by the casket carried by Uecker and Lock, and by about 20 others, including Bill Troop, Nick Sloan, Vicky Linchong, Richard Canning, Anthony Biggs, Michael Snyder (all the way from Oklahoma!), Looi van Kassel, members of the parish and representatives of the local media (Fig. 1). The procession was made in solemn silence; when the grave was reached, the funeral service was conducted by the lay-reader (Fig. 2).

It was fitting that, at Purdy's funeral service, right next to her grave, a poem by Dame Edith should be read (Fig. 3). The one we chose, 'How

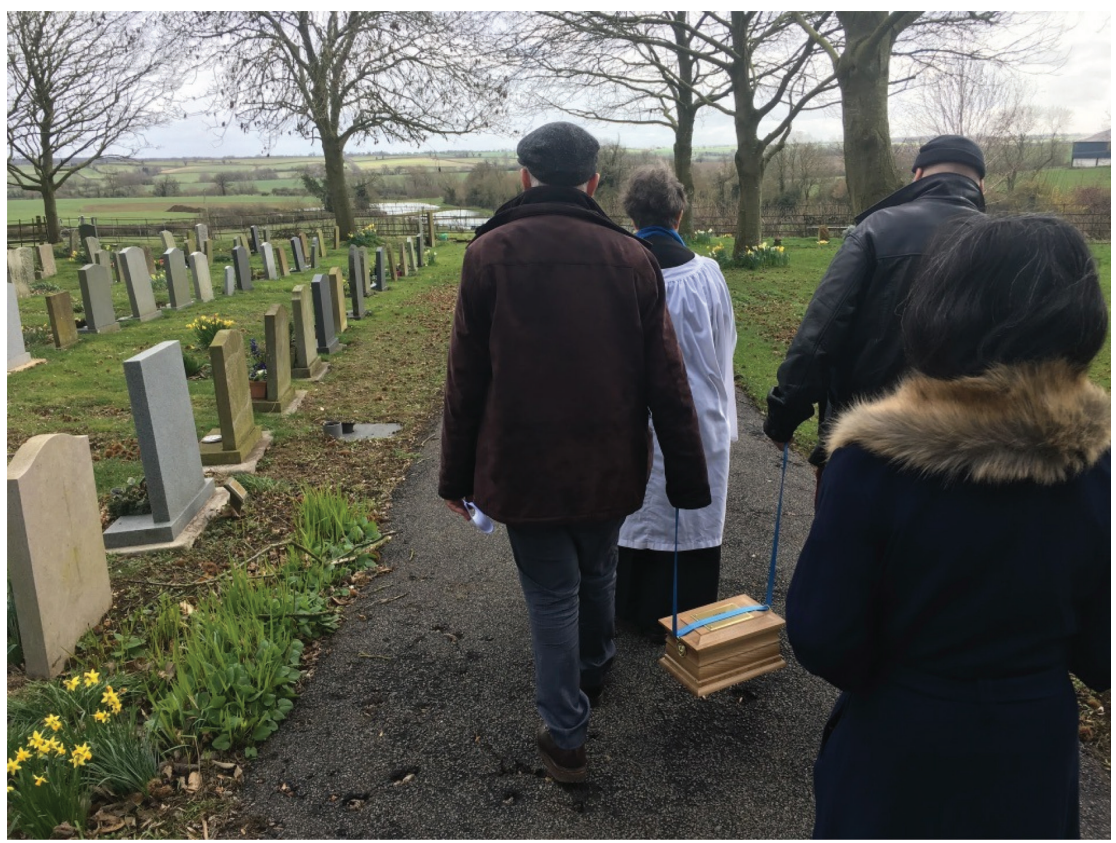

Fig. 1 Weedon Lois churchyard. James Purdy's funeral procession headed by lay-reader Wiggy Smith. Copyright Looi Van Kessel and reproduced with his permission. 


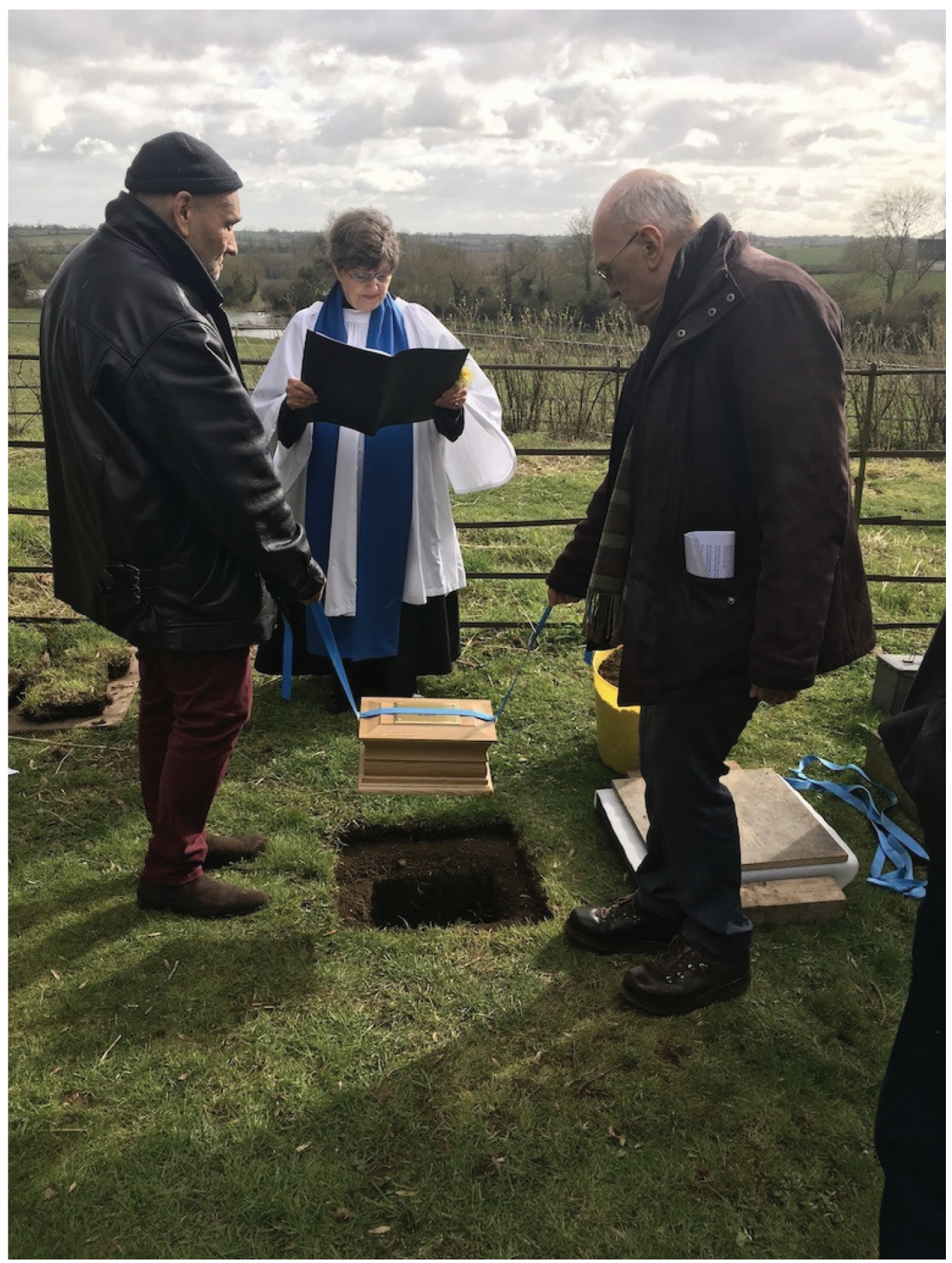

Fig. 2 John Uecker and Charles Lock lower the casket holding Purdy's ashes. Copyright Looi Van Kessel and reproduced with his permission.

Many Heavens..., would be suitable for any funeral: a search online led us not only to the passage from John Donne to which it alludes but to a later poem that alludes to both, by P. K. Page (a Canadian poet born in 


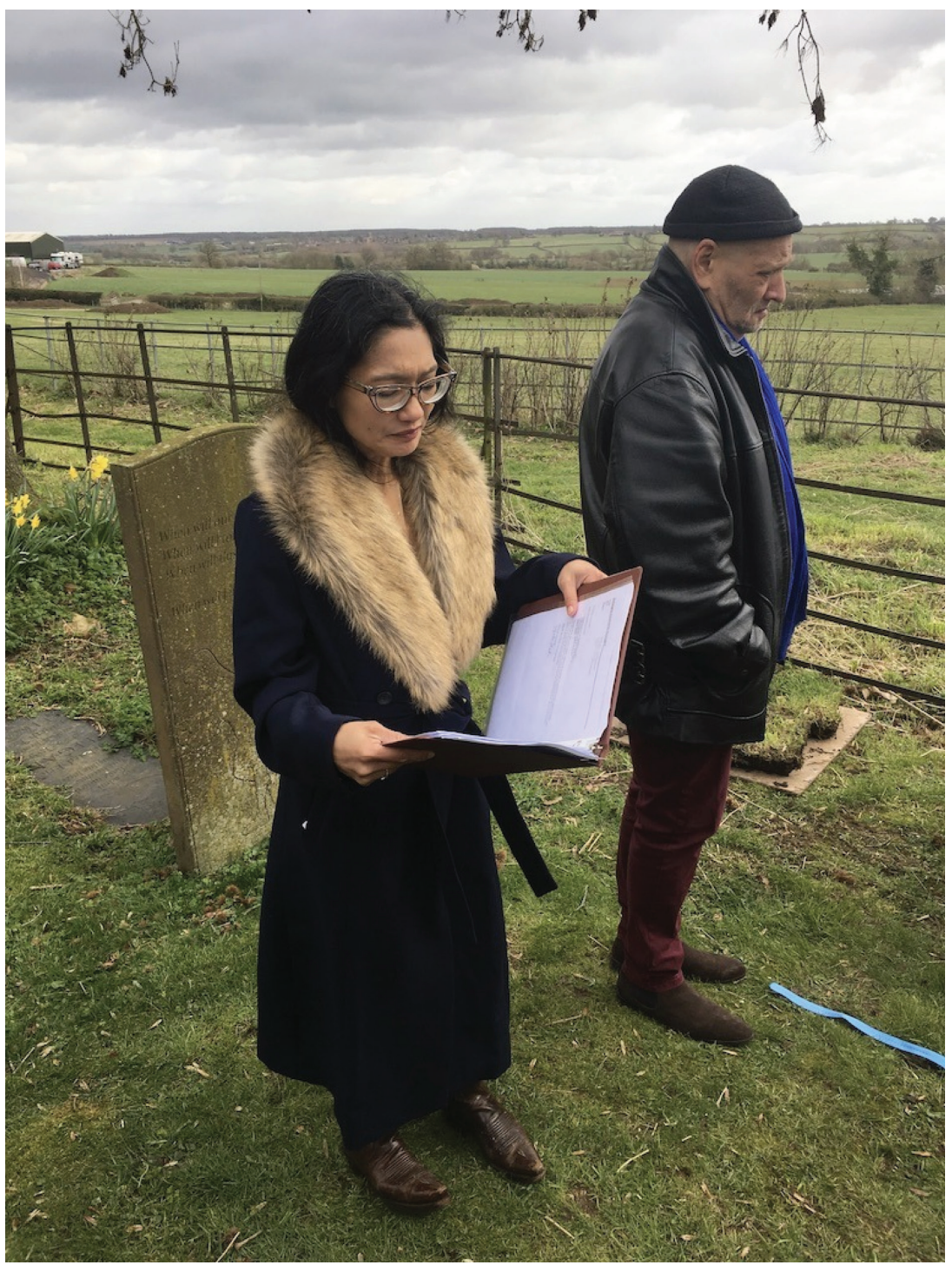

Fig. 3 Maria Cecilia Holt with John Uecker. Copyright Looi Van Kessel and reproduced with his permission.

England). These three texts are brought together on 'skybluemindblog' as 'Three Songs of Gold'. We altered the order of the texts, with acknowledgment to the blog, and retitled the sequence 'A Catena for Weedon Lois', voiced by myself and Charles Lock: 


\section{A Catena for Weedon Lois \\ How Many Heavens ...}

The emeralds are singing on the grasses,

And in the trees the bells of the long cold are ringing, -

My blood seems changed to emeralds like the spears

Of grass beneath the earth pulsing and singing.

The flame of the first blade

Is an angel piercing through the earth to sing

'God is everything!

The grass within the grass, the angel in the angel, flame

Within the flame. And $\mathrm{He}$ is the green shade that came

To be the heart of shade'.

The grey-beard angel of the stone,

Who has grown wise with age, cried 'Not alone

Am I within my silence, - God is the stone in the still stone, the silence laid In the heart of silence.'...

- Edith Sitwell (1887-1964)

God is so omnipresent, as that the Ubiquitary will needs have the body of God everywhere - will needs have God not only to be in everything, but to be everything - that God is an angel in an angel and a stone in a stone, and a straw in a straw.

- John Donne (1573-1631), Sermon VII

\section{Song ... Much of It Borrowed}

How beautifully it sings.

How beautifully Sitwell sang it.

How beautifully Donne began it:

'that God is an angel in an angel

and a stone in a stone

and a straw in a straw'.

I knew it all before

but The Canticle of the Rose

a long time on my shelf

and hidden by some flaw -

a kind of shelf in myself -

was suddenly visible 
And that golden rain of poems that glorious storm of poems sang until they were heard: that God is a poet in a poet a poem in a poem and a word in a word.

- P. K. Page (1916-2010)

After the casket was lowered by both John Uecker and Charles Lock, and before the stone was laid, Uecker was given a trowel and was the first to scatter soil (Fig. 4), on the pattern of Antigone's request and nature's ordaining:

Look: the body, just mounded over with light dust: you see? Not buried really, but as if they'd covered it just enough for the ghost's peace. ${ }^{44}$

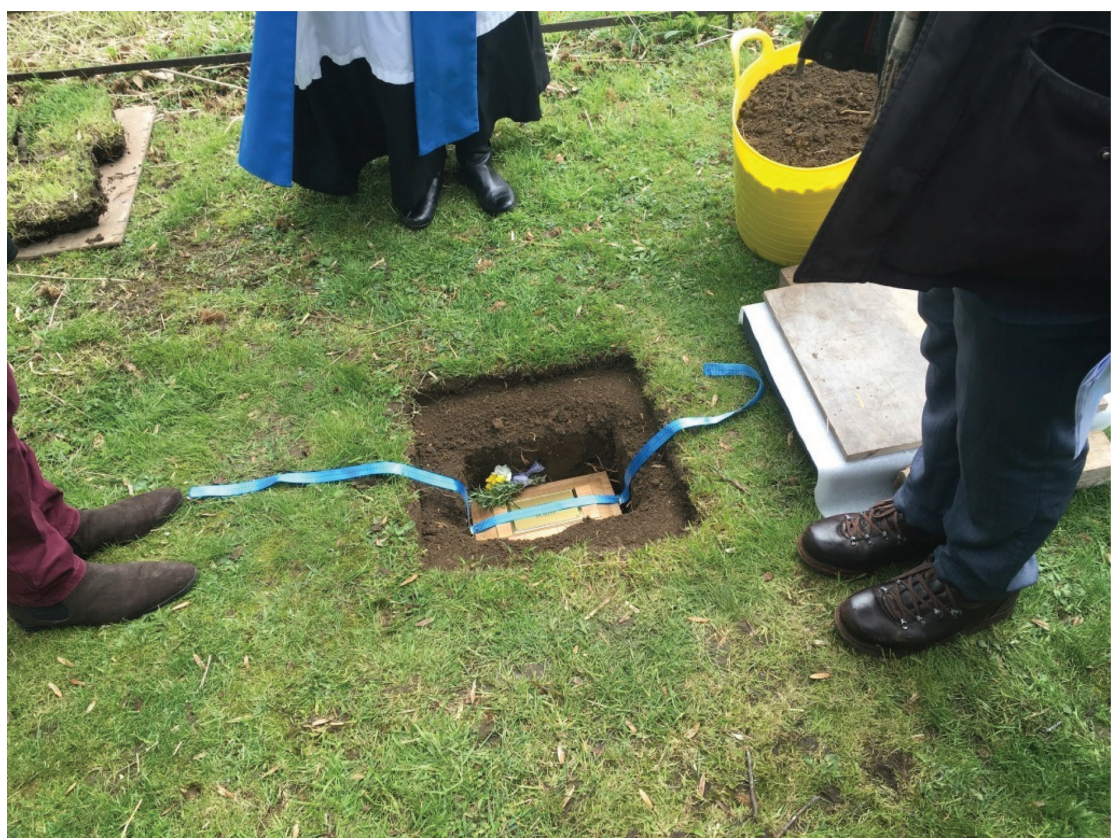

Fig. 4 Dust to dust, ashes to ashes. Copyright Looi Van Kessel and reproduced with his permission. 


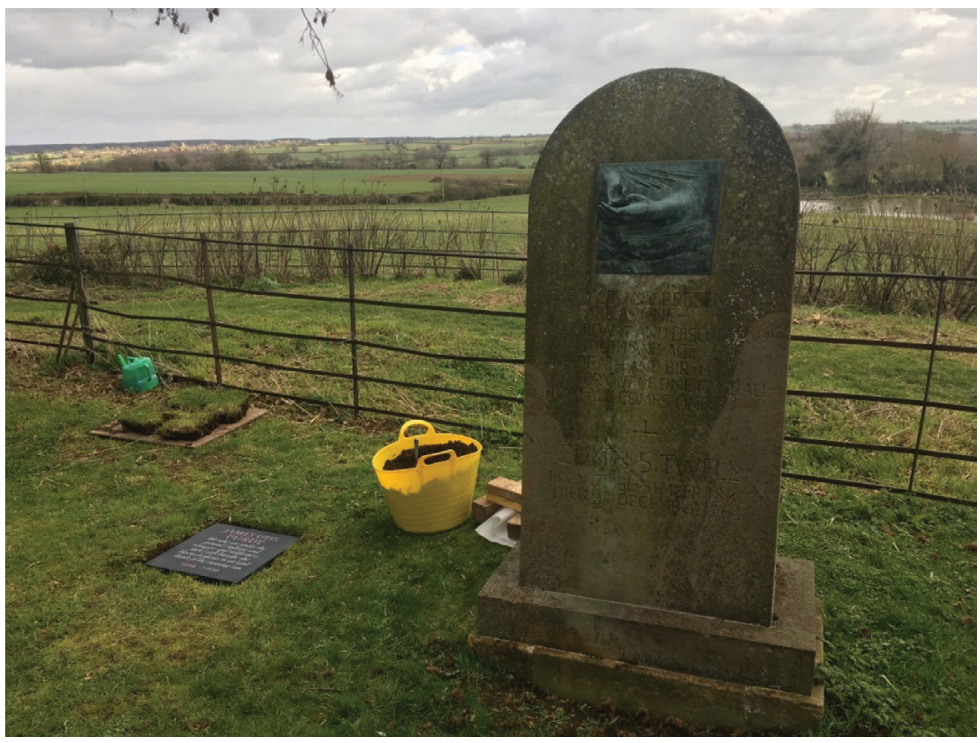

Fig. 5 The stone marking the grave of Edith Sitwell: hands by Henry Moore; lettering by Ralph Beyer. Copyright Looi Van Kessel and reproduced with his permission.

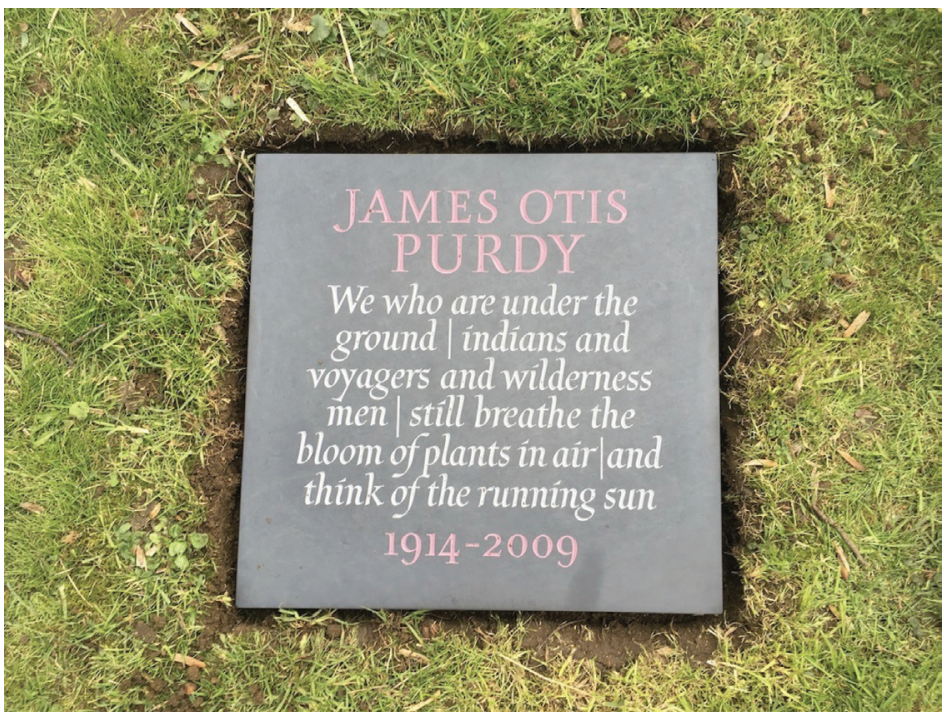

Fig. 6 Grave of James Purdy; lettering by Nicholas Sloan. Copyright Looi Van Kessel and reproduced with his permission. 


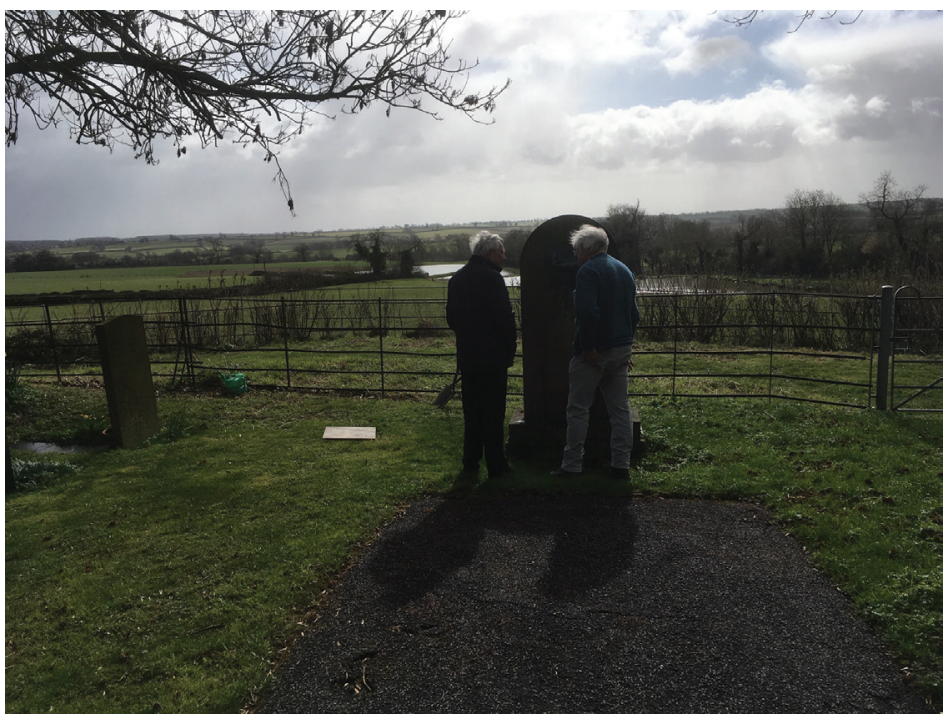

Fig. 7 Nicholas Sloan: (r) examining Dame Edith Sitwell's monument while preparing grave for Purdy's ashes. Copyright Charles Lock and reproduced with his permission.

The last book published by Purdy in his lifetime, Selected Plays (2009), bears this dedication:

For the two who stood behind me,

Tennessee Williams

John Uecker

Dame Edith Sitwell no longer stands behind Purdy on his mantelpiece in Brooklyn; now, in Weedon Lois, her stone overlooks his (Figs. 5 and 6). What has been narrated here is the chronicle of a funeral foretold and a grief assuaged.

\section{WORKS CITED}

Baglione, John Michael. 'Bridge of Sorrow, by Way of Faulkner.' The Harvard Gazette, 20 July 2017, https://news.harvard.edu/gazette/story/2017/07/plaque-honoring-faulknercharacter-to-be-reinstalled-on-charles-river-span/. Date accessed: 2 September 2019.

Bak, John. Tennessee Williams: A Literary Life. New York: Palgrave Macmillan, 2013.

Ballin, Michael and Charles Lock (eds.). 'The Correspondence of James Purdy and John Cowper Powys 1956-1963.' The Powys Journal 23 (2013) 6-114. 
Barron, Fred. 'Interview with James Purdy.' Penthouse Magazine, July 1974, 89-112.

Brook, Peter. The Empty Space: A Book About the Theatre. New York: Simon \& Schuster, 1996.

Browne, Thomas. In: Geoffrey Keynes (ed.), Sir Thomas Browne: Selected Writings. London: Faber \& Faber, 1968.

Grimes, William. 'James Purdy, a Literary Outsider With a Piercing Vision, Is Dead at 94.' New York Times, 13 March 2009.

'James Purdy (1914-2009)'. Interview Magazine, 24 March 2009. https://www.interviewmagazine.com/culture/james-purdy. Date accessed: 30 July 2019.

Lahr, John. Tennessee Williams: Mad Pilgrimage of the Flesh. New York: W. W. Norton, 2014.

Lock, Charles. 'Versions or Perversions: James Purdy and John Cowper Powys.' Powys Journal 26 (2016) 97-116.

Loxton, Howard. 'The Paradise Circus'. British Theatre Guide. https://www.britishtheatreguide.info/reviews/the-paradise-ci-playground-thea-16643. Date accessed: 3 September 2019.

Male, Andrew. 'I'm not a gay writer, I'm a monster": How James Purdy Outraged America.' The Guardian, 11 March 2019.

Michaud, Jon. 'The Strange, Unsettling Fiction of James Purdy.' The New Yorker, 21 July 2015, https://www.newyorker.com/books/page-turner/the-strange-unsettling-fiction-ofjames-purdy. Date accessed: 8 June 2019.

Morrow, Bradford. 'An Interview with James Purdy Conducted by Bradford Morrow.' In: Bradford Morrow (ed.), Conjunctions 3: Bi-Annual Volumes of New Writing. New York: Conjunctions, 1982, 97-111.

Peters, Carole. 'Re: Ashes'. Message to Charles Lock. 15 July 2015. E-mail.

Purdy, James. 63: Dream Palace. London: Victor Gollancz, 1957.

Purdy, James. Eustace Chisholm and the Works. London: Jonathan Cape, 1968.

Purdy, James. The House of the Solitary Maggot. London: Peter Owen, 1986.

Salter, Elizabeth. The Last Years of a Rebel: A Memoir of Edith Sitwell. London: Bodley Head, 1967.

Sitwell, Edith. 'Two Variations on a Theme.' The Song of the Cold. London: Macmillan, 1945.

Sitwell, Edith. In: John Lehmann and Derek Parker (eds.), Selected Letters. London: Macmillan, 1970.

Sontag, Susan. 'Laughter in the Dark.' New York Times, 25 October 1964, http://movies2.nytimes.com/books/00/03/12/specials/sontag-purdy.html. Date accessed: 29 August 2019.

Strausbaugh, John. 'Foment.' New York Press, 2-8 April 1997.

Turnbaugh, Douglas Blair. 'James Purdy; Playwright.' PAJ: A Journal of Performance and Art 20:2 (1998) 73.

Uecker, John. 'Two Visionaries.' James Purdy: Selected Plays. Chicago: Ivan R. Dee, 2009, ix-xii.

Uecker, John. 'Re: Visiting NYC Weekend June 27-28.' Received by author, 16 June 2015.

Uecker, John. James Purdy: Memento Mori. http://jamespurdy.org/generic.php?id=10. Date accessed: 8 June 2019.

Vidal, Gore. 'James Purdy: The Novelist as Outlaw.' The New York Times, 27 February 2005.

\section{ABOUT THE AUTHOR}

Maria Cecilia Holt has a doctorate from Harvard University's Divinity School. Her thesis is on the importance of Renaissance humanism for early modern encounters with the 'New World'. She has conducted research on the 'textuality of textiles' as well as on burial and oratory, both in early Christianity and in missionary accounts of indigenous funeral traditions in Southeast Asia. E-mail:maa324@mail.harvard.edu. 


\section{NOTES}

1 See Ballin, Michael and Charles Lock (eds.), 'The Correspondence of James Purdy and John Cowper Powys 1956-1963.' The Powys Journal 23 (2013) (15).

2 See Associated Press. 'James Purdy dies at 94; Writer Best Known for Underground Classics.' Los Angeles Times, 19 March 2009, https://latimes.com/local/obituaries/la-mejames-purdy19-2009mar19-story.html. Date accessed: 31 August 2019.

3 Sontag, Susan. 'Laughter in the Dark.' New York Times, 25 October 1964, http://movies2. nytimes.com/books/00/03/12/specials/sontag-purdy.html. Date accessed: 29 August 2019.

4 See Turnbaugh, Douglas Blair. 'James Purdy; Playwright.' PAJ: A Journal of Performance and Art 20:2 (1998) (73).

5 See Loxton, Howard. 'The Paradise Circus'. https://www.britishtheatreguide.info/reviews/the-paradise-ci-plaground-thea-16643. Date accessed: 2 September 2019.

6 See Male, Andrew. “'I'm not a gay writer, I'm a monster": How James Purdy Outraged America.' The Guardian, 11 March 2019. https://www.theguardian.com/books/2019/mar/11/ james-purdy-trump-america-gay-writer-monster. Date accessed: 2 September 2019.

7 See Sitwell, Edith. In: John Lehmann and Derek Parker (eds.), Selected Letters. London: Macmillan, 1970 (210).

8 See Baglione, John Michael. 'Bridge of Sorrow, by Way of Faulkner.' The Harvard Gazette, 20 July 2017, https://news.harvard.edu/gazette/story/2017/07/plaque-honoringfaulkner-character-to-be-reinstalled-on-charles-river-span. Date accessed: 8 June 2019.

9 Purdy, James. I am Elijah Thrush (1972) (44).

10 Purdy, James. Eustace Chisholm and the Works. London: Jonathan Cape, 1968 (116).

11 Barron, Fred. 'Interview with James Purdy.' Penthouse Magazine, July 1974 (90).

12 See Ballin, Michael and Charles Lock, 2013 (82).

13 Browne, Thomas. In: Geoffrey Keynes (ed.), Sir Thomas Browne: Selected Writings. London: Faber \& Faber, 1968 (115).

14 Purdy, James, 63: Dream Palace (79).

15 Transcribed by bookseller: 'James Purdy, 63: Dream Palace, Victor Gollancz, London, 1957, 12mo. 192 pp. Signed by Purdy on title-page. Cloth binding in clipped dustwrapper, edgewear, else good condition. (96160). In text "little bugger" crossed out and mother fucker written in, with note: "corrected by the author at the behest of Dame Edith Sitwell”. Bauer Rare Books, San Diego, CA: Inventory \# 10828.' https://www.abebooks. com/servlet/BookDetailsPL?bi=30036234178. Date accessed: 20 June 2019. See Lock, Charles. 'Versions or Perversions.' Powys Journal 26 (2016) (102-103).

16 John Uecker. 'Two Visionaries.' James Purdy: Selected Plays. Chicago: Ivan R. Dee, 2009 (xii).

17 Among the writers credited with having worked on the draft of Tennessee Williams's last play are Gavin Lambert, Gore Vidal and Peter Bogdanovich.

18 See Bak, John. Tennessee Williams: A Literary Life. New York: Palgrave Macmillan, 2013 (261).

19 Personal communication with John Uecker, 3 May 2019. See Lahr, John. Tennessee Williams: Mad Pilgrimage of the Flesh. New York: W. W. Norton, 2014 (583-586).

20 See undated letter from Tennessee Williams to James Purdy in Uecker, John. James Purdy: Memento Mori. http://jamespurdy.org/generic.php?id=10. Date accessed: 8 June 2019.

21 Ibidem.

22 Ballin and Lock (49).

23 Skype conversations with John Uecker, 27 April 2019 and 3 May 2019.

24 Leslie Morris of Houghton Library to the author: 'Please pass on to Mr. Uecker my gratitude; I've no doubt the material will be of interest to researchers' in Morris, Leslie. 'Follow Up' (17 July 2015). 
25 Uecker, 'Re: Thank you and tomorrow (29 June 2015)' Messages received 5 July 2015.

26 Peters-King, Carole. 'Re: Ashes'.

27 This wooden spoon was bought at a hardware store in Harvard Square, Cambridge, Massachusetts, near the non-fictional watch-shop where the fictional Quentin Compson had taken his grandfather's watch prior to his death. Crossing the Brooklyn Bridge with James's ashes I realised that the spoon had been purchased from the very store where Quentin would have acquired his flatirons.

28 Sitwell, Edith. 'Two Variations on a Theme.' The Song of the Cold. London: Macmillan, 1945 (39).

29 Dame Edith Sitwell's grave features a sculpture by Henry Moore and lettering carved by Ralph Beyer celebrated for the 'Tablets of the Words' in Coventry Cathedral.

30 Polyneices was Oedipus's son, expelled from Thebes after his father's patricide and incest are discovered, and later killed by his own brother in single combat. In Sophocles' play Antigone, his corpse is left unburied.

31 See Instagram: 37,875 posts (on 28 April 2020) https://www.instagram.com/explore/ tags/passedaway/?hl=en.

32 Purdy, James, The House of the Solitary Maggot (1974) (9).

33 'James Purdy (1914-2009)'. Interview Magazine. 24 March 2009. https://www.interviewmagazine.com/culture/james-purdy. Date accessed: 30 April 2020.

34 Brook, Peter. The Empty Space: A Book About the Theatre. New York: Simon \& Schuster, 1996 (122).

35 Strausbaugh, John. 'Foment.' New York Press. 2-8 April 1997.

36 See Grimes, William. 'James Purdy, a Literary Outsider With a Piercing Vision, Is Dead at 94.' New York Times, 13 March 2009, https://www.nytimes.com/2009/03/14/ books/14purdy.html. Date accessed: 3 September 2019.

37 See https://www.britishtheatreguide.info/reviews/the-paradise-ci-playground-thea-16643. Date accessed: 10 April 2020.

38 Peters-King, Carole. 'James Purdy.' Received by author, 6 June 2018. In late 2018 the Revd Carole Peters-King was transferred to another diocese within the Church of England, and Weedon Lois was thereafter in the cure of Wiggie Smith, a lay-reader, who would conduct the funeral.

39 Uecker, John. Re: Visiting.

40 See Morrow. 'An Interview with James Purdy.' In Conjunctions (100-101).

41 See Salter, Elizabeth. The Last Years of a Rebel: A Memoir of Edith Sitwell. London: Bodley Head, 1967 (88).

42 Salter, Elizabeth. The Last Years of a Rebel: A Memoir of Edith Sitwell. London: Bodley Head, 1967 (88).

43 See Vidal, Gore. 'James Purdy: The Novelist as Outlaw.' The New York Times, 27 February 2005, https://www.nytimes.com/2005/02/27/books.

44 Sophocles. Antigone. Trans. Dudley Fitts and Robert Fitzgerald (11.216-19). 